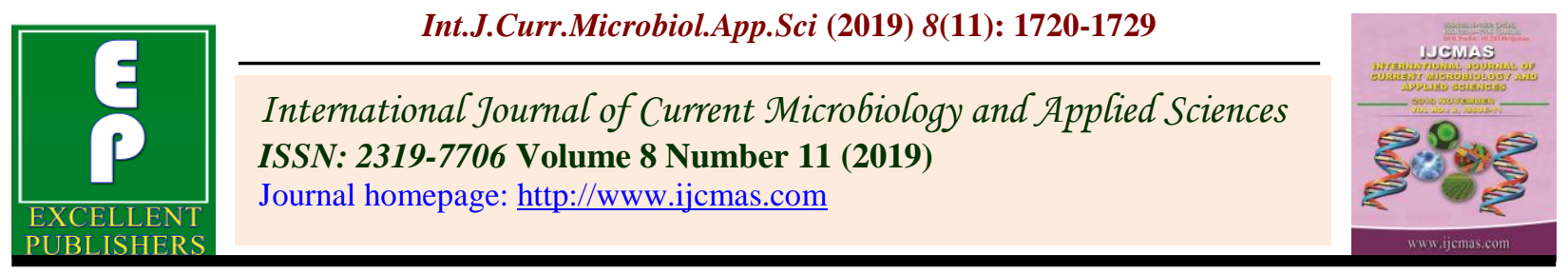

Original Research Article

https://doi.org/10.20546/ijcmas.2019.811.200

\title{
Relationship between Bioactive Components and Antioxidant Capacity of Some Commonly Consumed Vegetables in Punjab
}

\author{
Neerja Singla, Rohini Jain* and Priya Singla
}

Department of Food and Nutrition, Punjab Agricultural University, Ludhiana, India

*Corresponding author

\section{A B S T R A C T}

Keywords

Antioxidant

activity,

Flavonoids,

Phenolics,

Vegetables

Article Info

Accepted:

12 October 2019

Available Online:

10 November 2019
Many potential compounds such as flavonoids, phenolics and carotenoids possess anti-oxidant activity. Various categories of vegetables like green leafy, roots and tubers and other vegetables have these bioactive compounds and potent antioxidant activity. Total anti-oxidant activity and its correlation with total phenolics and flavonoids among various vegetables commonly consumed in Punjab (India) have not been much reported. The aim of this research was to determine the antioxidant capacity from methanol extracts of various vegetables and its correlation with the total flavonoid and phenolic content. Among all the vegetables, bathua leaves (Chenopodium album) were found to have highest phenolic and flavonoid content i.e. $247.20 \mathrm{mg}$ GAE$/ 100 \mathrm{~g}$ and $225.10 \mathrm{mg} \mathrm{RE} / 100 \mathrm{~g}$, respectively. The maximum total antioxidant capacity by FRAP was observed in fenugreek leaves (Trigonella foenumgraecum L.) i.e. $171.91 \mathrm{mg}$ TE/100g. Bathua leaves (Chenopodium album) were also found to have maximum antioxidant activity as measured by DPPH radical scavenging activity i.e. $126.80 \mathrm{mg} \mathrm{TE} / 100 \mathrm{~g}$. Total antioxidant activity correlated significantly with the total phenolic content of all vegetables $(p<0.01)$. However, non-significant correlation was observed between flavonoid content and total antioxidant activity.

\section{Introduction}

Fruits and vegetables have been gaining great attention among consumers because they play an important role in the human health and diet. Being considered as wholesome foods, the nutritional value of vegetables and fruits is attributed to the optimal mix of phytochemicals which are mainly constituted by fibres, natural antioxidants and bioactive components. Anti-oxidants are the substances which are capable of inhibiting the oxidative stress in the body caused by production of free radicals during metabolic reactions in the body. These free radicals are the agents which are involved in the pathogenesis of various non-metabolic disorders and degenerative diseases such as diabetes, Parkinson's and Alzheimer's diseases, cancers, asthma and atherosclerosis (Podsedek, 2007; Dasgupta and De, 2007; Turkmen et al., 2005 and Cai et al., 2004). 
Regular consumption of plant foods rich in anti-oxidant compounds inhibits the oxidative stress leading to degenerative diseases. These beneficial effects have been reported due to the presence of phytochemicals present in plants such as phenolic compounds (e.g., phenolic acids, flavonoids, quinones, lignans, stilbenes, coumarins, tannins), nitrogenous compounds (alkaloids, amines, betalains), endogenous metabolites, vitamins ( $\mathrm{C}$ and $\mathrm{E})$, and terpenoids (including carotenoids) (Cai et al., 2004). The protective effect of bioactive components in fruits and vegetables is primarily due to the reduction in oxidative stress, which is caused when the formation of reactive oxidants (most importantly reactive oxygen, nitrogen and iron species) is higher in the antioxidant defence system. Due to the possession of high antioxidant activity by these bioactive compounds, great interest has risen towards the relationship between phytochemical compounds and incidence of metabolic diseases (Nilsson and Stegmark 2004).

It has been reported that with increase in every serving of fruit and vegetable, the risk of various cancers, cardiovascular diseases and mortality is reduced by $15 \%, 30 \%$ and $20 \%$, respectively (Steimez and Potter 1996; Rimm et al., 1996), which can be credited to the presence of different antioxidant compounds in fruits and vegetables such as vitamin $\mathrm{C}$ and E, carotenoids, lycopenes, polyphenols and other phytochemicals (Prior and Cao 2000).

According to recent studies, different phytochemicals in common fruits and vegetables have multiple benefits including scavenging of oxidative radicals, strengthening of the defence system, regulating gene expression for the process of cell proliferation, maintaining hormone metabolism, and antibacterial and antiviral properties (Halvorsen et al., 2006). The present study was conducted to analyze the bioactive compounds and total antioxidant capacity of commonly consumed vegetables in Northern India especially Punjab and to derive associated correlations, which can prove to be of enormous benefit to human health.

\section{Materials and Methods}

\section{Plant materials}

A total of 15 commonly consumed vegetables (other vegetables, roots and tubers and green leafy vegetables) were collected from five locations of the local market of Ludhiana, Punjab which were further combined to withdraw a uniform sample.

All the vegetables were thoroughly cleaned and washed with distilled water to remove the dirt and other impurities. The samples of edible portions of all the vegetables were homogenized with the help of pestle and mortar and immediately processed for the extraction of bioactive components using standard procedures.

\section{Extraction of bioactive components - phenolic and antioxidant compounds from sample}

Samples (5 g) were homogenized in $80 \%$ aqueous methanol, acidified to $\mathrm{pH} 2.0$ with $6 \mathrm{~N}$ Hydrochloric acid by shaking at room temperature for 30 minutes and the supernatant was saved.

The residue was re-extracted twice with $80 \%$ ethanol for complete removal of phenolic and antioxidant compounds. The procedure was repeated two times. Pooled supernatants were centrifuged at $6000 \mathrm{rpm}$ for 15 minutes and then filtered through Whatman No.1 filter paper. Finally the volume was made upto to $50 \mathrm{ml}$ with the solvent, transferred to micro centrifuge tubes and stored at $-20^{\circ} \mathrm{C}$ for analysis. 
Determination of total phenol (FolinCiocalteu method)

Total phenolic compounds were determined using a modified Folin-Ciocalteau colorimetric method (Singleton et al., 1999).

Briefly, $0.5 \mathrm{ml}$ of sample aliquot of sample was taken and volume was made up to $1.5 \mathrm{ml}$ with distilled water. Further, $0.5 \mathrm{ml}$ of FolinCiocalteau reagent was added followed by 10 $\mathrm{ml}$ of $7.5 \% \mathrm{Na}_{2} \mathrm{CO}_{3}$.

It was incubated at $37^{\circ} \mathrm{C}$ for 60 minutes. The absorbance of blue-colored complex solution was read at $750 \mathrm{~nm}$ using UVspectrophotometer. Different concentrations of gallic acid $(5-20 \mu \mathrm{g} / \mathrm{mL})$ were used to construct a calibration curve. The results were expressed as miligram of gallic acid equivalent per hundred gram (mg GAE/100 g).

\section{Determination of Flavonoid content (Zhishen et al., 1999)}

Two $\mathrm{ml}$ of sample aliquot was taken in a test tube and volume was made up to $5 \mathrm{ml}$ with distilled water. Further, $0.3 \mathrm{ml}$ of $5 \%$ sodium nitrite was added to it. After $5 \mathrm{~min}, 0.6 \mathrm{ml}$ of $10 \%$ aluminium chloride was also added and mixed thoroughly. After keeping the test tubes again for $6 \mathrm{~min}, 2 \mathrm{ml}$ of $1 \mathrm{~N}$ sodium hydroxide was added and mixed.

In the end, the volume was made up to $10 \mathrm{ml}$ by adding $2.1 \mathrm{ml}$ distilled water. The absorbance of resulting pink colour was read at $510 \mathrm{~nm}$ against blank.

Standard series of known concentration of Rutin $(50-200 \mu \mathrm{g})$ were also made by taking different concentrations i.e. 0.5, 1.0, 1.5, 2.0 $\mathrm{ml}$ rutin aliquots and treated same as sample. The results were expressed as mg RE/ $100 \mathrm{~g}$ of flavonoids.

\section{Determination of Total antioxidant capacity by Ferric Reducing Antioxidant Power (FRAP) assay}

Ferric reducing antioxidant power (FRAP) was determined in sample extracts according to Benzie and Strain (1999) and modified by Tadhani et al., (2007). This method is based on the ability of the sample to reduce ferric $\left(\mathrm{Fe}^{3+}\right)$ to ferrous $\left(\mathrm{Fe}^{2+}\right)$ ions. In the presence of TPTZ (2,4,6-Tris (2-pyridyl)-s-triazine) the $\mathrm{Fe}^{2+}-\mathrm{TPTZ}$ complex exhibits blue colour which can be read at $593 \mathrm{~nm}$.

Sample aliquots $(0.1 \mathrm{ml})$ were taken and the volume was made up to $0.3 \mathrm{ml}$ with distilled water. Then, $1.8 \mathrm{ml}$ of FRAP working reagent was added to it After incubating for $10 \mathrm{~min}$ at room temperature, the absorbance was measured at $593 \mathrm{~nm}$ against blank. Similarly, the standard series with known concentration of Trolox $(0.5-2 \mu \mathrm{g})$ was also developed with same procedure as sample. The results were expressed as mg TE per $100 \mathrm{~g}$ sample.

\section{Determination of total antioxidant capacity by DPPH (2,2-Diphenyl-1-picrylhydrazyl) Radical Scavenging Activity}

This method is based on the ability of the antioxidant to scavenge the DPPH cation radical (Brand-Williams et al., 1995). Sample aliquots i.e. $0.3 \mathrm{ml}$ was taken in a test tube. The volume was made up to $1 \mathrm{ml}$ with methanol.

After this, $3 \mathrm{ml}$ of DPPH reagent was added to the test tubes, mixed properly and incubated for $20 \mathrm{~min}$ at $37^{\circ} \mathrm{C}$. After the incubation, the absorbance of the resulting oxidized solution was read at $517 \mathrm{~nm}$ against methanol as blank. Standard series of known concentration of $10 \mathrm{mg} \%$ Trolox $(5-20 \mu \mathrm{g})$ by taking concentrations as $0.05,0.1,0.15,0.2 \mathrm{ml}$ aliquot was made and treated same as sample. The results were expressed as $\mathrm{mg} \mathrm{TE} / 100 \mathrm{~g}$. 


\section{Statistical analysis}

Assays were performed in triplicate for each sample. Results were expressed in terms of mean values \pm standard deviation $(\mathrm{SD})$. To determine whether the bioactive compounds contributed to the antioxidant capacity, pearson's correlation coefficients were calculated at $1 \%$.

\section{Results and Discussion}

Total Phenolic (TPC) and Flavonoid (TFC) Content of vegetables

Phenolic compounds are natural antioxidants present in plant foods and they have been reported to have beneficial effects on human health as they act as reducing agents, hydrogen donators and single oxygen quenchers (Chang et al., 2001), thereby reducing the incidence of various degenerative diseases.

Total phenolic content (TPC) of the various green leafy vegetables under study varied from 60.12 to $247.05 \mathrm{mg} \mathrm{GAE} / 100 \mathrm{~g}$ (Table 1). TPC among various green leafy vegetables was found in the order of Bathua $>$ Spinach $>$ Fenugreek leaves $>$ Green amaranth $>$ Mustard. Total polyphenol content in Kale (green leafy vegetable) has been reported as $171.27 \mu \mathrm{g}$ GAE/mg of sample (Sikora et al., 2008). In the present study, the TPC in mustard leaves was found to be 60.12 $\mathrm{mg}$ GAE/100 $\mathrm{g}$ which is similar to the literature i.e. $62.62 \mathrm{mg} \mathrm{GAE} / 100 \mathrm{~g}$ (Bembem 2014). The phenols in spinach and bathua leaves were found to be 128.04 and $247.05 \mathrm{mg}$ GAE $/ 100 \mathrm{~g}$, respectively. These values are approximately equivalent with the findings to the values of $196.3 \mathrm{mg} / 100 \mathrm{~g}$ and 253.5 $\mathrm{mg} / 100 \mathrm{~g}$ in spinach and bathua leaves, respectively (Kaur and Kapoor, 2002). Among various other vegetables analysed for their total phenolic content, lady's finger was found to have highest content (151.7 mg GAE/100g) followed by bottle gourd, pumpkin, French beans and bitter gourd, respectively. Total Flavonoid content of above said vegetables was found to be in descending order of pumpkin $>$ lady's finger $>$ bitter gourd $>$ French beans>bottle gourd. Findings from another study revealed a higher value of TPC in bitter gourd procured from thailand as $224 \mathrm{mg}$ GAE/100g dry sample (Kubola and Siriamornpun 2008). TPC of $35.2 \mathrm{mg}$ $\mathrm{GAE} / 100 \mathrm{~g}$ in French beans reported in present study was quite lower as compared to that reported in other study which was 97.0 mg/100g (Kaur and Kapoor, 2002).

Among another category of vegetables i.e. Roots and tubers, five vegetables namely colocasia, radish, carrot, turnip and sweet poattao were analysed for their TPC and TFC. For TPC, the value in ascending order were carrot> sweet potato> radish> colocasia> turnip i.e. turnip was found to have highest TPC as $117.1 \mathrm{mg}$ GAE/100g. A previous study has also reported TPC in turnip as 127.0 $\mathrm{mg} / 100 \mathrm{~g}$, which is comparable to the values in present study (Kaur and Kapoor 2002). However, in carrots, TPC was found to be $31.6 \mathrm{mg} \mathrm{GAE} / 100 \mathrm{~g}$, whereas in literature, higher values have been reported as $55 \mathrm{mg} /$ $100 \mathrm{~g}$ has been reported (Kaur and Kapoor 2002). Furthermore, another study conducted by Koley et al., 2014 reported that the total phenols in sixteen Indian carrot varieties ranged from 7.98 to $291.48 \mathrm{mg} / 100 \mathrm{~g}$. TPC in radish reported in the present study and in the literature (Sreeramulu and Raghunath, 2010) are found to be comparable. The values being 61.73 and $66.73 \mathrm{mg} \mathrm{GAE} / 100 \mathrm{~g}$, respectively.

Flavonoids are a group of secondary plant metabolites naturally found in fruits and vegetables, which helps to maintain the body's health and provides protection against various ailments. They also exhibit anti-nutritional properties due to their metal chelating 
properties. As depicted in Table 2, the highest content of total flavanoids among green leafy vegetables was found in the bathua leaves, followed by mustard, spinach, fenugreek and green amaranth, respectively. A previous study in the literature (Bembem, 2014) reported a value of $23.09 \mathrm{QE} / 100 \mathrm{~g}$, TFC in mustard leaves. However, in the present study, the value was found to be $129.09 \mathrm{mg}$ $\mathrm{RE} / 100 \mathrm{~g}$, the difference might be due to the method used for the estimation. The total flavonoid content in spinach was found to be $148.14 \mathrm{mg} \mathrm{RE} / 100 \mathrm{~g}$ which is slightly higher as compared to the value of $108.7 \mathrm{mg} \mathrm{QE} / 100$ $\mathrm{g}$ reported in another study (Singh et al., 2016).

The flavonoid content among other vegetables ranged from $20.12 \mathrm{mg} \mathrm{RE} / 100 \mathrm{~g}$ in bottle gourd to $65.21 \mathrm{mg} \mathrm{RE} / 100 \mathrm{~g}$ in pumpkin. The value for the flavonoid content of bitter gourd has been reported to be $80.5 \mathrm{mg} \mathrm{QE} / 100 \mathrm{~g}$ in the previous study by Singh et al., 2016, which is comparatively higher to the value reported in the present study i.e. $50.21 \mathrm{mg}$ $\mathrm{RE} / 100 \mathrm{~g}$. In contrast to the present study, the authors of the previous study analyzed flavonoid content in 62 Malaysian edible plants and reported the flavonoid content in pumpkin, lady's finger and french beans as $371.0,260$ and $172.5 \mathrm{mg} / \mathrm{kg}$ of dry weight, respectively (Miean and Mohamed, 2001).

The flavonoid content among roots and tubers was found to be low as compared to green leafy vegetables and other vegetables. Sweet potato was found to have the highest flavonoid content i.e. $48.1 \mathrm{mg} \mathrm{RE} / 100 \mathrm{~g}$ and carrot was found to have the lowest value $(6.12 \mathrm{mg}$ $\mathrm{RE} / 100 \mathrm{~g}$ ) among roots and tubers.

Table.1 Total Phenolic (TPC) and Total Flavonoid Content (TFC) of the vegetables

\begin{tabular}{|c|c|c|c|c|}
\hline S.No. & Samples & Scientific name & $\begin{array}{c}\text { Total Phenols } \\
\text { (mg GAE/100g) }\end{array}$ & $\begin{array}{c}\text { Total Flavonoid } \\
\text { (mg RE/100g) }\end{array}$ \\
\hline & \multicolumn{4}{|c|}{ Leafy vegetables } \\
\hline 1. & Mustard & Brassica campestris & $60.12 \pm 0.06$ & $129.09 \pm 0.07$ \\
\hline 2. & Bathua & Chenopodium album & $247.20 \pm 1.17$ & $225.10 \pm 1.64$ \\
\hline 3. & Spinach & Spinacia oleracea & $128.13 \pm 0.30$ & $148.14 \pm 0.24$ \\
\hline 4. & Fenugreek & Trigonella foenum-graecum $L$. & $93.66 \pm 1.58$ & $136.24 \pm 0.83$ \\
\hline \multirow[t]{2}{*}{5.} & Green amaranth & Amaranthus viridis & $86.50 \pm 2.21$ & $106.90 \pm 0.29$ \\
\hline & \multicolumn{4}{|c|}{ Other vegetables } \\
\hline 1. & Pumpkin & Cucurbita maxima & $39.40 \pm 1.23$ & $65.21 \pm 0.68$ \\
\hline 2. & Bottle gourd & Lagenaria vulgaris & $42.64 \pm 0.87$ & $20.12 \pm 0.21$ \\
\hline 3. & Bitter gourd & Momordica charantia & $34.74 \pm 0.58$ & $50.21 \pm 0.67$ \\
\hline 4. & French beans & Phaseolus vulgaris & $35.24 \pm 2.31$ & $42.97 \pm 0.74$ \\
\hline \multirow[t]{2}{*}{5.} & Lady's finger & Abelmoschus esculentus & $151.71 \pm 1.12$ & $64.80 \pm 0.98$ \\
\hline & \multicolumn{4}{|c|}{ Roots and tubers } \\
\hline 1. & Colocassia & Colacasia antiquorum & $74.57 \pm 0.58$ & $38.51 \pm 1.24$ \\
\hline 2. & Radish & Raphanus sativus & $61.73 \pm 2.04$ & $35.42 \pm 0.53$ \\
\hline 3. & Carrot & Daucus carota & $31.60 \pm 0.25$ & $6.12 \pm 0.29$ \\
\hline 4. & Turnip & Brassica rapa var. Rapa & $117.10 \pm 2.41$ & $21.90 \pm 0.25$ \\
\hline 5. & Sweet potato & Ipomoes batatas & $61.27 \pm 1.36$ & $48.10 \pm 1.07$ \\
\hline
\end{tabular}

Values are Mean $( \pm \mathrm{SD})$; GAE- Gallic Acid Equivalent; RE- Rutin Equivalent 
Table.2 Total antioxidant capacity of vegetables as measured by FRAP and DPPH

\begin{tabular}{|c|c|c|c|c|}
\hline $\begin{array}{l}\text { Sl } \\
\text { no. }\end{array}$ & Samples & Scientific name & $\begin{array}{c}\text { Ferric Reducing } \\
\text { Antioxidant Power } \\
\text { (FRAP) assay } \\
\text { (mg TE/100g) }\end{array}$ & $\begin{array}{l}\text { DPPH Radical } \\
\text { Scavenging } \\
\text { Activity } \\
\text { (mg TE/100g) }\end{array}$ \\
\hline & \multicolumn{4}{|c|}{ Leafy vegetables } \\
\hline 1. & Mustard & Brassica campestris & $104.30 \pm 0.24$ & $65.91 \pm 0.06$ \\
\hline 2. & Bathua & Chenopodium album & $76.20 \pm 1.08$ & $126.80 \pm 0.14$ \\
\hline 3. & Spinach & Spinacia oleracea & $54.34 \pm 0.14$ & $56.78 \pm 0.06$ \\
\hline 4. & Fenugreek & Trigonella foenum-graecum $L$. & $171.91 \pm 0.14$ & $29.7 \pm 0.51$ \\
\hline \multirow[t]{2}{*}{5.} & Green amaranth & Amaranthus viridis & $158.27 \pm 0.45$ & $78.10 \pm 0.52$ \\
\hline & \multicolumn{4}{|c|}{ Other vegetables } \\
\hline 1. & Pumpkin & Cucurbita maxima & $42.80 \pm 0.47$ & $31.51 \pm 1.15$ \\
\hline 2. & Bottle gourd & Lagenaria vulgaris & $31.90 \pm 0.34$ & $40.02 \pm 0.34$ \\
\hline 3. & Bitter gourd & Momordica charantia & $65.20 \pm 0.87$ & $24.25 \pm 2.05$ \\
\hline 4. & French beans & Phaseolus vulgaris & $22.60 \pm 0.67$ & $39.70 \pm 0.21$ \\
\hline \multirow[t]{2}{*}{5.} & Lady's finger & Abelmoschus esculentus & $31.50 \pm 0.51$ & $86.60 \pm 0.67$ \\
\hline & \multicolumn{4}{|c|}{ Roots and tubers } \\
\hline 1. & Colocassia & Colacasia antiquorum & $19.80 \pm 0.33$ & $75.03 \pm 1.84$ \\
\hline 2. & Radish & Raphanus sativus & $61.70 \pm 2.04$ & $24.02 \pm 1.02$ \\
\hline 3. & Carrot & Daucus carota & $57.75 \pm 0.24$ & $11.45 \pm 0.47$ \\
\hline 4. & Turnip & Brassica rapa var. rapa & $117.10 \pm 2.41$ & $14.90 \pm 0.27$ \\
\hline 5. & Sweet potato & Ipomoes batatas & $61.30 \pm 1.36$ & $19.20 \pm 1.01$ \\
\hline
\end{tabular}

Values are mean \pm SD

TE- Trolox Equivalent

Table.3 Correlation coefficient between total phenolic, flavonoid content and total anti-oxidant activity

\begin{tabular}{|c|c|}
\hline & $\mathbf{r}^{2}$ (Pearson Correlation coefficient) \\
\hline TPC vs TAC by FRAP & $0.542^{\mathrm{NS}}$ \\
\hline TPC vs TAC by DPPH & $0.001^{*}$ \\
\hline TFC vs TAC by FRAP & $0.142^{\mathrm{NS}}$ \\
\hline TFC vs TAC by DPPH & $0.004^{*}$ \\
\hline
\end{tabular}

*Correlation is significant at the 0.01 level (2-tailed).

NS- Non-significant

A wide range of total flavonoids i.e. 3.00 to $111.70 \mathrm{mg} / 100 \mathrm{~g}$ in carrot has been provided in the literature (Koley et al., 2014). A previous study has reported a significantly higher TFC in carrot i.e. $232.5 \mathrm{mg} / \mathrm{kg}$ of dry weight (Miean and Mohamed, 2001), while another study reported a value of 26.9 and $43.5 \mathrm{mg}$
$\mathrm{CE} / 100 \mathrm{~g}$ of flavonoids in carrot and radish respectively (Srivastava et al., 2013).

A wide range of values of phenols and flavonoids in various vegetables has been reported in the literature, which may be attributed to genetic variety or cultivar, 
season, soil condition, water availability, degree of maturity, method of estimation and standards used play an important role in determining the various bioactive components.

\section{Anti-oxidant capacity of vegetables}

Anti-oxidant capacity of various vegetables was studied by two methods i.e. by Ferric Reducing Assay Power (FRAP) and DPPH Radical Scavenging Activity. The results of anti-oxidant activity in various vegetables by both the methods have been presented in Table 2.

Total anti-oxidant activity as measured by FRAP assay was found to be highest (171.9 $\mathrm{mg}$ TE/100g) in fenugreek leaves, when measured by DPPH Radical Scavenging Activity, it was found to be lowest in fenugreek leaves (29.7 $\mathrm{mg} \mathrm{TE} / 100 \mathrm{~g})$. The TAC by FRAP assay among various leafy vegetables was in order of fenugreek> green amaranth $>$ mustard $>$ bathua $>$ spinach. So, the lowest value of TAA by FRAP assay was in spinach i.e. $54.34 \mathrm{mg} \mathrm{TE} / 100 \mathrm{~g}$.

TAC by DPPH Radical Scavenging Activity in mustard leaves (65.91 mg TE/100g) was comparable to that 69.44 per cent reported in the literature (Bembem, 2014). TAC by DPPH in kale leaves was 82.80 per cent which can be considered as comparable to those reported among various leafy vegetables in the present study.

On contrary to this, quite low values of TAC by $\mathrm{DPPH}$ in fenugreek $(25.7 \%)$ and spinach leaves $(20.4 \%)$ was reported in a previous study by Gacche et al., (2010).

Among other vegetables, TAC by FRAP assay was found to be higher $(65.2 \mathrm{mg} \mathrm{TE} / 100 \mathrm{~g})$ in bitter gourd, while it was lowest in lady's finger.
However, TAC as DPPH (\%) free radical scavenging activity was found to be higher in lady's finger ( $86.6 \mathrm{mg} \mathrm{TE} / 100 \mathrm{~g}$ ), followed by bottle gourd (40.02 mg TE/100g), French beans (39.7 mg TE/100g), pumpkin (31.5 mg $\mathrm{TE} / 100 \mathrm{~g})$ and bottle gourd (24.2 $\mathrm{mg}$ $\mathrm{TE} / 100 \mathrm{~g}$ ), respectively. The authors of a study have analyzed TAC by DPPH in some of the Asian vegetables and reported the comparable values of $43.8 \%$ and $40.7 \%$ in lady's finger and bottle gourd, respectively (Gacche et al., 2010). Kamath et al., (2015) had reported TAA as $15.05 \mathrm{mg}$ AAE/g in ridge gourd and $12.39 \mathrm{mg} \mathrm{AAE} / \mathrm{g}$ in cabbage, which are also categorized under other vegetables.

Among various roots and tubers analysed in the present study, radish and turnip were found to have almost similar values of TAC (by FRAP) i.e. 67.7 and $61.3 \mathrm{mg}$ TE/100g, respectively, while another study in the literature have reported very high values of 1294.36 and $422.56 \mathrm{mg} / 100 \mathrm{~g}$ in radish and sweet potato, respectively, estimated by similar method i.e. FRAP assay (Sreeramulu and Raghunath, 2010).

The differences might be credited to the varietal or agronomical differences which may vary from place to place. In addition to this, methods used to extract hydrophilic/lipophilic phases from vegetables also contribute significantly to the differences in the estimated values of antioxidant activity. TAC as measured by DPPH Radical Scavenging Activity was found to be highest in colocasia (75.03 $\mathrm{mg} \mathrm{TE} / 100 \mathrm{~g}$ ), followed by radish (24.02 TE/100g), sweet potato (19.20 TE/100g), turnip (14.90 TE/100g) and carrot (11.45 TE/100g), respectively. The value for TAA by DPPH in the literature (Sreeramulu and Raghunath, 2010) has been reported to be $29.02 \mathrm{mg} / 100 \mathrm{~g}$ in radish and $25.03 \mathrm{mg} / 100 \mathrm{~g}$ in sweet potato which are comparable to those reported in the present study. 
Correlation among bioactive components and total antioxidant capacity (TAC)

Pearson correlation coefficient was calculated to test the significance of relationship between the bioactive components (Total phenols and flavonoids) and total antioxidant activity. The relationship between the Total phenolic and flavonoid content with the Total Antioxidant capacity by DPPH was found to be significant $(\mathrm{p}<0.01)$. Similar findings have been observed in another study (Kaur and Kapoor, 2002). Another study by Sreeramulu and Raghunath (2010) also depicted a significant correlation $(\mathrm{p}<0.01)$ between TPC and AOA both in roots and tubers ( $\mathrm{r}$ values being 0.76 and 0.85 respectively with DPPH and FRAP) and other vegetables $(r=0.79$ and 0.85 with DPPH and FRAP). The associations between the bioactive components and TAC suggest that various phytochemicals found in the vegetables are capable of scavenging free radicals. A non-significant correlation was found in the bioactive components with the Total antioxidant capacity by FRAP assay. Findings from a study have also concluded that the phenolic contents and the antioxidant activities of vegetables correlated very well with the methods used for analysis (Stratil et al., 2006) (Table 3).

The antioxidant activity can be attributed to a number of molecules in the matrix under investigation, for instance ascorbate, GSH etc. The phenolic content in plant foods comprises flavonoids, phenolic acids, simple phenols, condensed hydrolysable tannins and lignans etc., which fluctuates widely during different seasons and different stages of the life cycle of a plant. The potential and presumptive antioxidant capacity of each of these components depends on the kind of test system employed.

The most commonly used methods FRAP and DPPH assess the potential of these compounds, which consists of their capacity to release hydroxyl ions responsible for neutralizing free radicals. Normally, the correlation between phenolics and antioxidant activity is high, it is interesting to analyze each class or compound and relate to the antioxidant potential.

Further, researches are needed to evaluate the specificity of phenolic compounds responsible for the antioxidant activity and the possible mechanisms responsible for their actions. Besides this, in vivo antioxidant assays are required for the confirmation of role of these species in prevention of various diseases.

\section{Acknowledgement}

The authors are grateful to the Indian Council of Agricultural Research (ICAR), New Delhi and Central Institute of Women in Agriculture (CIWA), Bhubaneswar for the financial support. Furthermore, we are thankful to Head, Department of Food and Nutrition, Punjab Agricultural University for the laboratory support.

\section{References}

Bembem K (2014) Effect of thermal treatments on antioxidative activity of selected vegetables. Ph.D dissertation, Punjab Agricultural University.

Benzie I F and Strain J J (1999) Ferric reducing/antioxidant power assay: Direct measure of total antioxidant activity of biological fluids and modified version for simultaneous measurement of total antioxidant power and ascorbic acid concentration. Methods in Enzymology 299:15-27.

Brand-Williams W, Cuvelier M E and Berset C L (1995) Use of a free radical method to evaluate antioxidant activity. LWT-Food Science and 
Technology 28:25-30.

Cai Y, Luo Q, Sun M and Corke H (2004) Antioxidant activity and phenolic compounds of 112 traditional Chinese medicinal plants associated with anticancer. Life Sciences, 74:21572184.

Chang S T, Wu J H, Wang S Y, Kang P L, Yang N S and Shyur L F (2001) Antioxidant activity of extracts from Acacia confuse bark and heartwood. Journal of Agricultural and Food Chemistry, 49:3420- 3424.

Dasgupta, N and De B (2007) Antioxidant activity of some leafy vegetables of India: Comparative study. Food Chemistry 101:471-474

Gacche, R N, Kabaliye V N, Dhole N A and Jadhav A D (2010) Antioxidant potential of selected vegetables commonly used in diet in Asian subcontinent. Indian Journal of Natural Products and Resources, 1: 306:13.

Halvorsen B L, Carlsen M H, Phillips K M, Bohn S K, Holte K, Jacobs D R and Blomhoff R (2006) Content of redoxactive compounds (i.e., antioxidants) in foods consumed in the United States. Am. J. Clin. Nutr. 84:95-135.

Kamath S D, Arunkumar D, Avinash N G and Samshuddin S (2015) Determination of total phenolic content and total antioxidant activity in locally consumed food stuffs in Moodbidri, Karnataka, India. Advances in Applied Science Research 6:99-102

Kaur C and Kapoor H C (2002) Anti-oxidant activity and total phenolic content of some Asian vegetables. International Journal of Food Science \& Technology 37:153-161.

Koley T K, Singh S, Khemariya P, Sarkar A, Kaur C, Chaurasia S N S and Naik P S (2014) Evaluation of bioactive properties of Indian carrot (Daucus $\begin{array}{lll}\text { carota } & \text { L.): } & \text { A chemometric }\end{array}$ approach. Food

Research

International 60:76-85.

Kubola J and Siriamornpun S (2008) Phenolic contents and antioxidant activities of bitter gourd (Momordica charantia L.) leaf, stem and fruit fractions extracts in vitro. Food Chemistry 110:881-890.

Miean K H and Mohamed S (2001) Flavonoid (myricetin, quercetin, kaempferol, luteolin and apigenin) content of edible tropical plants. J Agricultural and Food Chem 49:3106:12

Nilsson J and Stegmark R B (2004) Total antioxidant capacity in different pea (Pisum sativum) varieties after blanching and freezing. Food Chemistry 86:501-507.

Podsedek A (2007) Natural antioxidants and antioxidant capacity of Brassica vegetables: A review. LWT-Food Science and Technology 40:1-11

Prior R L and Cao G (2000) Antioxidant phytochemicals in fruits and vegetables - diet and health implications. Hortic Sci 35:588- 592.

Rimm E B, Ascherio A, Grovannucci E, Spielgelman D, Stampfer $M J$ and Willett W C (1996) Vegetable, fruit and cereal fiber intake and risk of coronary heart disease among men. JAMA 275:447-451

Sikora E, Cieslik E, Leszczynska T, FilipiakFlorkiewicz $\mathrm{A}$ and Pisulewski $\mathrm{P} \mathrm{M}$ (2008) The antioxidant activity of selected cruciferous vegetables subjected to aquathermal processing. Food Chemistry 107:55-59.

Singh J P, Kaur A, Shevkan K and Singh N (2016) Composition, bioactive compounds and antioxidant activity of common Indian fruits and vegetables. Journal of food science and technology 53:4056-4066.

Singleton V L, Orthofer R and LamuelaRaventos R M (1999) Analysis of total phenols and other oxidation substrates 
and antioxidants by means of FolinCiocalteu reagent. Methods of Enzymology 299:152-158.

Sreeramulu D and Raghunath M (2010) Antioxidant activity and phenolic content of roots, tubers and vegetables commonly consumed in India. Food Research International 43:1017-1020.

Srivastava M P, Tiwari R and Sharma N (2013) Assessment of phenol and flavonoid content in the plant materials. J New Biol Rep 2: 163-66.

Steimez K A and Potter J D (1996) Vegetables, fruits and cancer prevention: a review. J Am Diet Assoc 96:1027-1039.

Stratil S, Klejdus B and Kuban V (2006) Determination of total phenolic compounds and their antioxidant activity in vegetables- evaluation of spectrophotometric methods. J Agric Food Chem 54(3): 607-616.

Tadhani M B, Patel V H and Subhash R (2007) In vitro antioxidant activities of Stevia rebaudiana leaves and callus. Journal of Food Composition and Analysis 20: 323-329.

Turkmen N, Sari F and Velioglu Y S (2005) The effect of cooking methods on total phenolics and antioxidant activity of selected green vegetables. Food Chemistry 93:713-718.

Zhishen, J, Mengcheng $\mathrm{T}$ and Jianming $\mathrm{W}$ (1999) The determination of flavonoid contents in mulberry and their scavenging effects on superoxide radicals. Food Chemistry 64:555-559.

\section{How to cite this article:}

Neerja Singla, Rohini Jain and Priya Singla. 2019. Relationship between Bioactive Components and Antioxidant Capacity of Some Commonly Consumed Vegetables in Punjab. Int.J.Curr.Microbiol.App.Sci. 8(11): 1720-1729. doi: https://doi.org/10.20546/ijcmas.2019.811.200 